\title{
Biological therapies in monogenic autoinflammatory diseases: long-term efficacy and safety
}

\author{
Maria A Pelagatti', Alessandro Cattoni, Carmelo Rizzari \\ From 70th Congress of the Italian Society of Pediatrics, Joint National Meeting SIP, SICuPP, SITIP \\ Palermo, Italy. 11-14 June 2014
}

\section{Introduction}

Autoinflammatory diseases (AIDs) represent a group of monogenic disorders, related to mutations in genes encoding proteins involved in the regulation of inflammatory responses. The aims of therapy in AIDs patients are controlling disease activity, improving patient's quality of life and preventing long-term complications. Biological agents have recently changed the natural history and the prognosis of AIDs. According to a pathogenetic criterium, they can be classified as:

1 ) Anti-TNF agents: i) Etanercept, a dimeric fusion protein of TNFR2 linked with the Fc region of human IgG1, ii) Adalimumab, a fully human monoclonal antiTNF antibody, iii) Infliximab, a mouse/human chimeric monoclonal anti-TNF antibody [1,2].

2) Anti-IL-1 agents: i) Anakinra, a competitive IL-1 receptor antagonist, ii) Canakinumab, a fully humanized anti-IL-1 monoclonal antibody, iii) Rilonacept, a fusion protein of IL-1 extracellular domains and Fc region of human IgG [1].

3) Anti-IL-6 agents: Tocilizumab, a monoclonal antibody binding and inhibiting both soluble and membrane IL-6 receptor $[1,2]$.

\section{Clinical use of biological drugs in autoinflammatory disorders}

$\rightarrow$ Familiar Mediterranean Fever (FMF) is the only autoinflammatory disease in which a "classical" immunomodulator (colchicine) still plays a central role [3]. Nonetheless, a relevant number of non complete responders has been recently observed. According to the pivotal role of IL-1 in the pathogenesis of FMF [4,5], anti-IL-1 treatment has been employed in colchicine-resistant patients,

\footnotetext{
* Correspondence: marettapel@yahoo.it

Department of Pediatrics, University of Milano-Bicocca, San Gerardo Hospital,
} 20900 Monza (MB), Italy

with good response in terms of control of disease activity and systemic impairment [6,7].

$\rightarrow$ In TRAPS (TNF Receptor Associated Periodic Fever Syndrome) patients, the failure of Infliximab and Adalimumab in controlling inflammatory flares has been already described [8]. Etanercept does not completely normalize symptoms or acute phase reactants [9] and the progressive development of neutralizing antibodies may compromise its effectiveness [2]. On the other hand, recent papers have shown the dramatic and persistent efficacy of anti-IL-1 treatment in TRAPS patients [10,11].

$\rightarrow$ In CAPS (Cryopirin Associated Periodic Syndromes) patients treated with Anakinra, the clinical improvement appears to be strictly dependent on continuous drug administration [12,13]. Moreover, preliminary results on Rilonacept and Canakinumab seem to be promising [14-16].

$\rightarrow$ In Hyper-IgD (Mevalonate Kinase Deficiency), Anakinra has shown to be markedly effective in different case reports, while Etanercept provided variable results [2].

\section{Conclusions}

Although biologic agents are related to frequent side effects, their administration has revolutionized the clinical approach to AIDs patients. Further trials are needed to definitively assess their safety and efficacy.

\section{Published: 11 August 2014}

\section{References}

Gattorno M, La Regina M, Manna R, Martin A: An update on autoinflammatory diseases. New concepts for new and old diseases. Clin Exp Rehumatol 2009, 27:354-365.

2. Vitale A, Rigante D, Lucherini OM, Caso F, Muscari I, Magnotti F, Brizi MG, Guerrini S, Patti M, Punzi L, Galeazzi M, Cantarini L: Biological Treatments: new weapons in the management of monogenic autoinflammatory disorders. Meidators Inflamm 2013, 2013:939847. 
3. Rigante D, La Torraca I, Avallone L, Pugliese AL, Gaspari S, Stabile A: The pharmacologic basis of treatment with colchicine in Children with familiar mediterranean fever. Eur Rev Med Pharmacol Sci 2006, 10:173-178.

4. Fernandes-Alnemrni T, Wu J, Datta P, Miller B, Jankowski W, Rosenberg S, Zhang J, Alnemri ES: The pyroptosome: a supramolecular assembly of ASC dimers mediating inflammatory cell death via caspase- 1 activation. Cell Death Differ 2007, 14:1590-1604.

5. Chae JJ, Cho YH, Lee GS, Cheng J, Liu PP, Feigenbaum L, Katz SI, Kastner DL: Gain of function Pyrin Mutation Induce NLPR3 protein indedpendent interleukin-1 beta activation and severe autoinflammatory in mice. Immunity 2011, 34:755-768.

6. Ozen $\mathrm{S}$, Bilgner $\mathrm{Y}$, Aktay Ayaz $\mathrm{Y}$, Calguneri M: Anti interleukin 1 treatment for patients with familiar mediterranean fever resistant to conchicine. J Rheumatol 2011, 38:516-518.

7. Hashkes PJ, Spalding SJ, Giannini EH, Huang B, Johnson A, Park G, Barron KS, Weisman MH, Pashinian N, Reiff AO, Samuels J, Wright DA, Kastner DL, Lovell DJ: Rilonacept for colchicine-reistant or -intolerant familiar mediterranean fever: a randomized trial. Ann Intern Med 2012, 157:533-541.

8. Vaitla PM, Radford PM, Tighe PJ, Powell RJ, McDermott EM, Todd I, Drewe E: Role of interleukin 6 in patient with tumor necrosis factor receptorassociated periodic syndrome. Arthritis Rheum 2011, 63:1151-1155.

9. Bulua AC, Mogul DB, Aksentijevich I, Singh H, He DY, Muenz LR, Ward MM, Yarboro CH, Kastner DL, Siegel RM, Hull KM: Efficacy of Etanecrcept in tumor necrosis factor-associated periodic syndrome: a prospective, open label, dose-escalation study. Arthritis Rheum 2012, 64:908-913.

10. Gattorno M, Pelagatti MA, Meini A, Obici L, Barcellona R, Federici S, Buoncomagni A, Plebani A, Merlini G, Martini A: Persistent efficacy of anakinra in patients with tumor necrosis factor-receptor associated periodic syndrome. Arthritis Rheum 2008, 58:1516-1520.

11. Lachmann HL, Obici A, Meini A, Tormey V, Abrams K, Davis N, Bahnsali SG, Gattorno M: Canakinumab in patients with TRAPS. Pediatr Rheumatol Online J 2013, 11 (Suppl 1):189.

12. Hawkins PN, Lachmann HJ, McDermott MF: Interleukin-1 receptor antagonist in the Muckle-Wells Syndrome. N Engl J Med 2003, 348:2583-2584

13. Hoffman HM, Rosengren S, Boyle DL, Cho JY, Nayar J, Mueller JL, Anderson JP, Wanderer AA, Firestein GS: Prevention of cold-associated acute inflammation in familiar cold autoinflammatory syndrome by interleukin-1 receptor antagonist. Lancet 2004, 364:1779-1785.

14. Goldback-Mansky R, Shroff SD, Wilson M, Snyder C, Plehn S, Barham B, Pham TH, Pucino F, Wesley RA, Papadopolous JH, Weinstein SP, Mellis SJ, Kastner DL, Meini A: A pilot study to evaluate the safety and efficacy of long-acting interleukin-1 inhibitor rilonacept (interleukin-1 trap) in patients with familiar cold autoinflammatory syndrome. Arthritis Rheum 2008, 58:2432-2442.

15. Hoffman HM, Throne ML, Amar NJ, Sebai M, Kivitz AJ, Kavanaugh A, Weinstein SP, Belomestnov P, Yancopoulos GD, Stahl N, Mellis SJ: Efficacy and safety of rilonacept (interleukin-1 trap) in patients with cryopirinassociated periodic syndromes: results from two sequential placebocontrolled studies. Arthritis Rheum 2008, 58:2443-2452.

16. TerHaar N, Lachmann H, Özen S, Woo P, Uziel Y, Modesto C, Woo P, Koné-Paut Y, Cantarini L, Insalaco A, Neven B, Hofer M, Rigante D, AlMayouf S, Touitou I, Gallizzi R, Papadopoulou-Alataki E, Martino S, Martino S, Kuemmerle-Deshner J, Obici L, lagaru N, Simon A, Nielsen S, Martini A, Ruperto N, Gattorno M, Frenkel J, Paediatric Rheumatology International Trials Organisation (PRINTO), the Eurofever/Eurotraps Projects: Treatment of autoinflammatory diseases: results from the Eurofever Registry and literature review. Ann Rheum Dis 2013, 7:678-685.

doi:10.1186/1824-7288-40-S1-A26

Cite this article as: Pelagatti et al:: Biological therapies in monogenic autoinflammatory diseases: long-term efficacy and safety. Italian Journal of Pediatrics 2014 40(Suppl 1):A26.

\section{Submit your next manuscript to BioMed Central and take full advantage of:}

- Convenient online submission

- Thorough peer review

- No space constraints or color figure charges

- Immediate publication on acceptance

- Inclusion in PubMed, CAS, Scopus and Google Scholar

- Research which is freely available for redistribution

Submit your manuscript at www.biomedcentral.com/submit 